Research Article

\title{
The Experiences of the Prospective Information Technology Teachers Taking the Multimedia Design and Production Course with Project- Based Learning Method: A Case Study
}

\author{
Murat ÇOBAN ${ }^{1 *}$

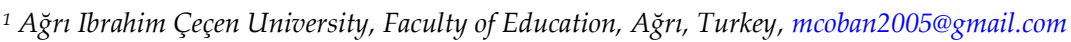 \\ *Corresponding Author: mcoban2005@gmail.com
}

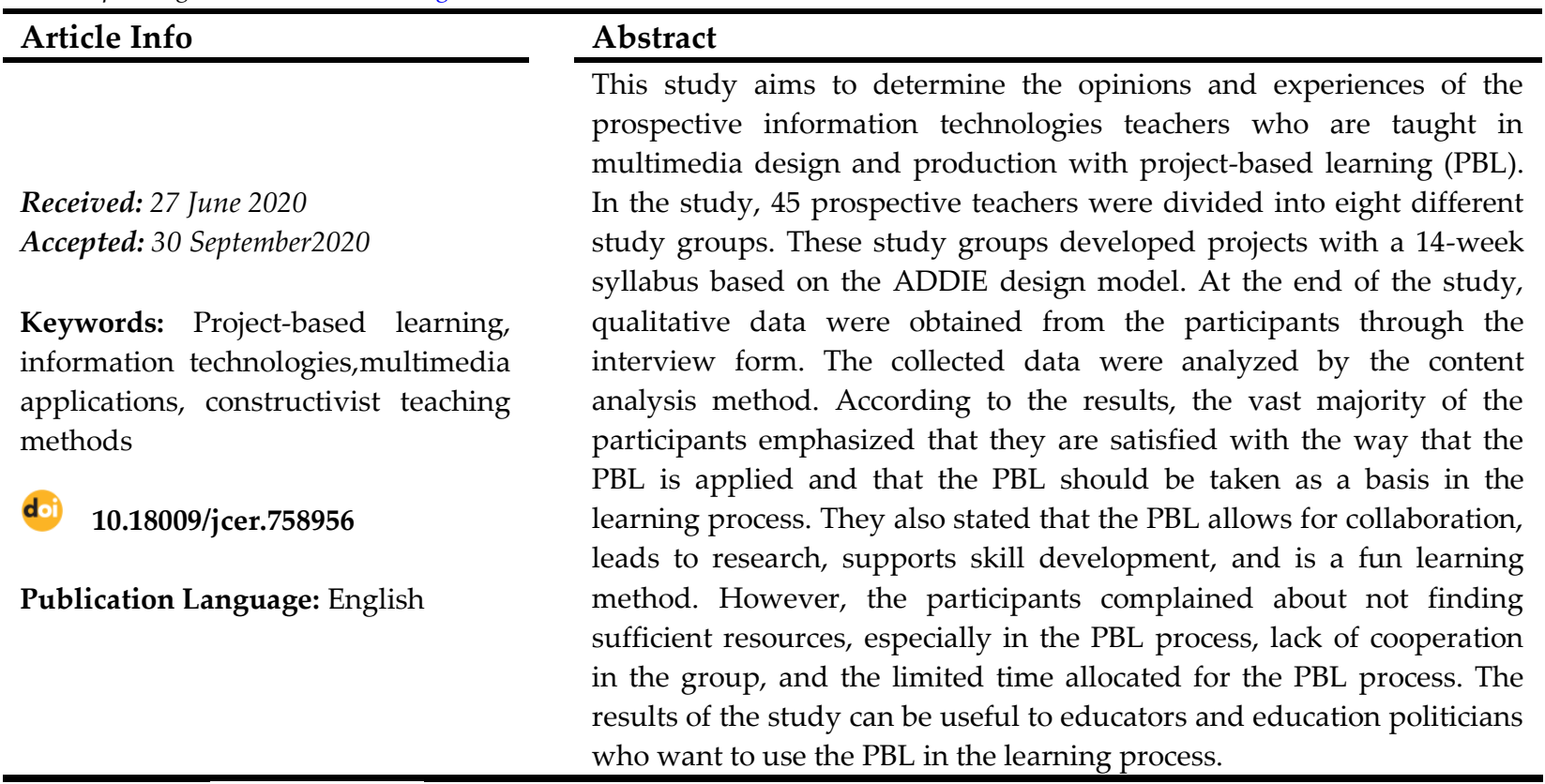

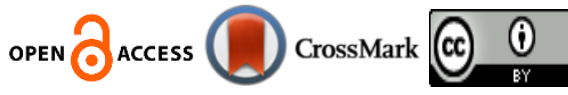

To cite this article: Çoban, M. (2020). The experiences of the prospective information technology teachers taking the multimedia design and production course with project-based learning method: a case study. Journal of Computer and Education Research, 8 (16), 720-737. http://doi.org/10.18009/758956

\section{Introduction}

Today, many educators tend to conduct research on which teaching and assessment method can be the most effective and efficient in their field (Saraçoglu \& Kahyaoğlu, 2018; Guo, Saab, Post \& Admiraal, 2020). In this context, different learning and teaching strategies are searched for answers to this question in the vast majority of researches. It is stated that the constructivist learning approach is more attractive for educators in the process of seeking answers, which started with a behavioral learning approach and continues with a constructivist learning approach today (Ahmad, Ching, Yahaya \& Abdullah, 2015). According to the constructivist approach based on the work of Jean Piaget, it is argued that 
people cannot be given information directly, but that students should configure their own knowledge through their previous knowledge and experience (Chisanu, Sumalee, Issara \& Charuni, 2012). In the constructivist learning approach, students can learn through active learning (Apaydin \& Kandemir, 2017), developing their critical skills, and guiding their learning processes. For this reason, in the classes where the constructivist approach is applied, students have many opportunities, such as learning by doing, developing their critical skills, and shaping their learning processes as active participants (Gulbahar \& Tinmaz, 2006).

Especially given that higher education institutions focus on providing students with research skills rather than on providing them with professional knowledge and skills (Guo et al., 2020), it can be argued that teaching approaches that give the opportunity to constructivist learning are more important. It is therefore emphasized that the constructivist teaching approach gives students the opportunity to solve a real problem and to structure their knowledge. Also, thanks to the constructivist approach, students get the opportunity to bridge the gap between the knowledge they learn in school and practice in real life (Holmes, 2012). In this context, project-based learning (PBL), one of the constructivist teaching approaches, is an attractive way in the process of using theoretical knowledge in real life (Chen \& Yang, 2019). The PBL is a constructivist teaching method that supports students' participation in the problem-solving process (Doppelt, 2003). According to another definition, the PBL refers to an inquiry-based teaching method that helps students structure their knowledge in the process of developing real-world products and performing meaningful projects (Krajcik \& Shin, 2014). As a result, in the basic philosophy of the PBL, there is a motivating effect that causes the student's perception of "I must learn" rather than the "I need to learn" message that the teacher emphasizes on the student (Lenz, Wells \& Kingston, 2015, p. 68).

During the PBL, students have to define the problem, discuss their ideas, make inquiries, collect data, analyze the collected data, share their findings with their peers, and solve problems (Bell, 2010). While the students experience the PBL, they are also provided to understand the related concepts (Krajcik \& Czerniak, 2014, p. 6). In addition, since the PBL is related to real-world experiences, students can increase learning motivations (Bender, 2012, pp. 8-10; Krajcik \& Czerniak, 2014, p. 6), help them focus on learning content (Holm, 2011), 
positively affect their attitudes towards learning (Tseng, Chang, Lou \& Chen, 2013) and help develop their metacognitive skills, which allows them to monitor and organize their own performances (Markham, Larmer \& Ravits, 2003, p. 7). In this context, the PBL is used in many different disciplines. Among these disciplines, there are disciplines such as science (Tierney et al., 2020), Science, Technology, Engineering and Mathematic (STEM) (Tseng et al., 2013), nursery (Wu et al., 2018), foreign language (Sadeghi, Biniaz \& Soleimani, 2016), information technologies (Celik et al., 2018).

Considering that the PBL is a teaching approach that places the student in the center (Krajcik \& Shin, 2014), it is important to explore students' responses, perspectives, and expectations about this approach. There are some recent studies in the literature on students' responses to the PBL during the learning process. For example, Assaf (2018) found that the PBL on language education motivates most of the students, improves their attitudes towards the course, and develops their performance. Vogler et al. (2018) emphasized that teachers should monitor students in the learning process and guide them in case of need, according to their findings from students within the framework of the PBL. They also recommended that students should consider the resource and time parameters they need during the PBL.

Berbegal-Mirabent, Gil-Doménech and Alegre (2017) stated that the PBL gives students the opportunity to learn based on experience. Raycheva, Angelova and Vodenova (2017) stated that students generally need more teacher support and time as a result of the PBL they applied. They also emphasized that the students were pleased with the new learning items of course objectives and knowledge, but that the students faced various difficulties within the group. For example, some students stated that the responsibilities or duties within the group were not shared equally, that team members were not responsible for completing the tasks in the project, and that they did not support each other sufficiently. As a result of one of the PBL applied, it was stated that this type of learning can be challenging and confusing for students, especially in the first weeks of the course (Dauletova, 2014). In addition, the researcher argued that the students' encounter with a new learning experience might cause an enormous transformation of the students' past learning habits, cognitive structures, and role perception and cause them to react negatively to this new learning approach by creating a shock effect. However, with time, patience, and a 
positive attitude, the researcher emphasized that students can learn to adopt this alternative teaching approach by overcoming their initial concerns and fears.

Wu et al. (2018) stated that the nursing department students who use e-books in the PBL increased their motivation and performance. However, they found that the new teaching approach increased the cognitive load levels of the students, and accordingly, they should make more efforts in the learning process. Additionally, in the research conducted by Yam and Rossini (2010), some difficulties encountered during the PBL were noted. As a result of the research, it is stated that PBL activities can cause workload problems. They also emphasized that both teachers and students have a lack of experience and need to develop special materials for the out-of-class studying process.

In light of these studies, it is emphasized that more studies should be carried out to evaluate the effectiveness of the PBL (Guo et al., 2020). Therefore, the aim of this study is to reveal the experiences of the prospective teachers who experience the PBL. Accordingly, research questions are formulated as follows:

1) What are the experiences of the prospective teachers regarding the PBL?

2) What are the difficulties of the prospective teachers regarding the PBL?

\section{Methodology}

\section{Research Model}

In this study, a case study model, one of the qualitative research approaches, was used. Case studies allow a detailed investigation of the data collected on a particular topic. In other words, factors related to a situation (such as environment, individuals, events, processes) are investigated with a holistic approach, and they are focused on how they affect the situation and how they are affected (Yildirim \& Simsek, 2008). This research model was used to describe the students' experiences in the PBL process and the problems they encountered in more detail.

\section{Participants}

This research was conducted in Turkey's Agri Ibrahim Cecen University, which is one of the easternmost universities. The research participants include 45 fourth grade prospective teachers studying in the Department of Computer Education and Instructional Technologies. The prospective teachers, who were divided into eight study groups (around 
5-7 participants in each group) in the spring semester of 2017-2018, were determined using the purposive sampling method. This sampling method was preferred because it gives speed and practicality to the research process (Fraenkel \& Wallen, 2000; Yildirim \& Simsek, 2008). In addition, this method was chosen due to the product-oriented planning of the learning contents related to the Multimedia Design and Production course, which is based on the PBL process. Table 1 shows the details of the participants.

Table 1. Distribution of participants by group and gender

\begin{tabular}{cccc}
\hline Group Number & Female & Male & Total \\
\hline 1 & 4 & 1 & 5 \\
2 & 4 & 2 & 6 \\
3 & 4 & 2 & 6 \\
4 & 4 & 1 & 5 \\
5 & 2 & 3 & 5 \\
6 & 1 & 5 & 6 \\
7 & 3 & 2 & 5 \\
8 & 1 & 6 & 7 \\
\hline Total & 23 & 22 & 45 \\
\hline
\end{tabular}

\section{The Role of the Researcher}

In line with his learning and teaching experiences, the researcher takes the role of advising the participants, providing theoretical information about the course, and coordinating the activities related to the projects. In addition, the researcher tries to meet the expectations of the participants regarding the technical, hardware, and other problems they need during the project development process.

\section{Research Process}

The study groups took the Multimedia Design and Production course, which is offered four hours a week (2 hours of theory, 2 hours of practice), with the curriculum guidance detailed in Table 2. The syllabus prepared by the researcher and covering 14 weeks was based on the ADDIE design model, a system-based approach model, which is also defined as the core model, and it is characterized by this abbreviation because it consists of the initials of the Analysis, Design, Development, Implementation, and Evaluation phases (Danks, 2011).

In the analysis phase of the model, the current situation is analyzed, and the source of the problem is identified. In the design phase, the most appropriate solution strategies are determined by using the information obtained in the analysis process. During the 
development phase, the product decided on at the design phase is developed by using the tools and resources determined. During the implementation phase, the developed product is applied to the target audience. In the final phase, the evaluation phase, the extent to which the product developed meets the specified targets is tested. In this context, the evaluation phase is directly related to other phases (Arkun, 2007).

Table 2. Syllabus for multimedia design and production course

\begin{tabular}{|c|c|}
\hline Week & Unit Title \\
\hline Week_1 & Meeting, working on the syllabus \\
\hline Week_2 & $\begin{array}{l}\text { Multimedia theories and approaches } \\
\text { Multimedia design principles } \\
\text { Cognitive load theory and principles } \\
\text { Presentation of sample projects }\end{array}$ \\
\hline Week_3 & $\begin{array}{l}\text { Introduction of some software that can be } \\
\text { prepared multimedia } \\
\text { - Unity 3D software } \\
\text { - Augmented Reality (Augmented reality } \\
\text { technology), Vuforia, Aurasma, Metaio, } \\
\text { and Build software } \\
\text { - Promotion of Virtual Reality, HTC Vive, } \\
\text { and other hardware } \\
\text { - 360 video software } \\
\text { - Virtual worlds } \\
\text { - Adobe Flash software } \\
\text { - Ulead Video Studio (Video editing } \\
\text { software) } \\
\text { - 3D Studio Max modeling software } \\
\text { - Blender 3D modeling software }\end{array}$ \\
\hline
\end{tabular}

Week_4 Multimedia project preparation process PHASE-1

Analysis phase Tasks

Provision of the syllabus, introduction of resources.

Presentation of the instructor.

Displaying video and other resources on the Internet.

Presentation of the project preparation draft to the students.

Task 1: Adding the needs analysis to the report.

- Needs analysis

Week_5 Multimedia project preparation process PHASE-1

Analysis phase

- Pre-post analysis

- Audience analysis

Week_6 Multimedia project preparation process PHASE-1

Analysis phase

- Technology analysis

- Task analysis

- Setting goals

- Environment analysis

Task_2: Adding the pre-post analysis and target audience analysis to the report.

Task_3: Task_3: Adding technology analysis, task analysis, setting goals and environment analysis processes to the report. 


\begin{tabular}{|c|c|c|}
\hline Week_7 & $\begin{array}{l}\text { Multimedia project preparation process } \\
\text { PHASE-2 } \\
\text { Design phase } \\
\text { Determining the strategies for the } \\
\text { development process } \\
\text { Drafting the project } \\
\text { Determination of properties of multimedia } \\
\text { Creating the contents }\end{array}$ & $\begin{array}{l}\text { Task_4: Submitting the activity } \\
\text { schedule to the instructor and adding } \\
\text { it to the project report. }\end{array}$ \\
\hline Week_8 & $\begin{array}{l}\text { Multimedia project preparation process } \\
\text { PHASE-2 } \\
\text { Design phase }\end{array}$ & $\begin{array}{l}\text { Task_5: Creating the template of the } \\
\text { design process and adding it to the } \\
\text { report. }\end{array}$ \\
\hline Week_9 & $\begin{array}{l}\text { Multimedia project preparation process } \\
\text { PHASE-3 } \\
\text { Development phase }\end{array}$ & $\begin{array}{l}\text { Development and follow-up of the } \\
\text { project, providing necessary support } \\
\text { and feedback. }\end{array}$ \\
\hline Week_10 & $\begin{array}{l}\text { Multimedia project preparation process } \\
\text { PHASE-3 } \\
\text { Development phase }\end{array}$ & $\begin{array}{l}\text { Development and follow-up of the } \\
\text { project, providing necessary support } \\
\text { and feedback. }\end{array}$ \\
\hline Week_11 & $\begin{array}{l}\text { Multimedia project preparation process } \\
\text { PHASE-3 } \\
\text { Development phase }\end{array}$ & $\begin{array}{l}\text { Task_6: Sharing and presenting the } \\
\text { developed product. } \\
\text { Providing product feedback/ } \\
\text { corrections by the instructor. }\end{array}$ \\
\hline Week_12 & $\begin{array}{l}\text { Multimedia project preparation process } \\
\text { PHASE-4 } \\
\text { Implementation phase }\end{array}$ & $\begin{array}{l}\text { Task_7: Implementation of the } \\
\text { developed product to the target } \\
\text { audience. }\end{array}$ \\
\hline Week_13 & $\begin{array}{l}\text { Multimedia project preparation process } \\
\text { PHASE- } 5 \\
\text { Evaluation phase }\end{array}$ & $\begin{array}{l}\text { Task_8: Obtaining and interpreting } \\
\text { the results of the target audience (such } \\
\text { as satisfaction, attitude, opinion, } \\
\text { experience). }\end{array}$ \\
\hline Week_14 & $\begin{array}{l}\text { FINAL EXAI } \\
\text { (Delivery of the project report and }\end{array}$ & $\begin{array}{l}\text { JATION } \\
\text { ortfolio files to the instructor) }\end{array}$ \\
\hline
\end{tabular}

The study groups followed the syllabus given to them at the beginning of the semester and developed multimedia teaching materials. The prospective teachers worked in cooperation in the working group to which they belonged. In this context, they freely choose the software offered to them in collaboration during the development process of multimedia materials. Participants generally developed multimedia materials using the Unity $3 D$ game engine. In addition, as the group members benefit from ready-made models, they have designed and developed multimedia components (such as audio, graphics, video, animation, coding). In Figure 1, some screenshots related to the products developed by the prospective teachers are seen. 

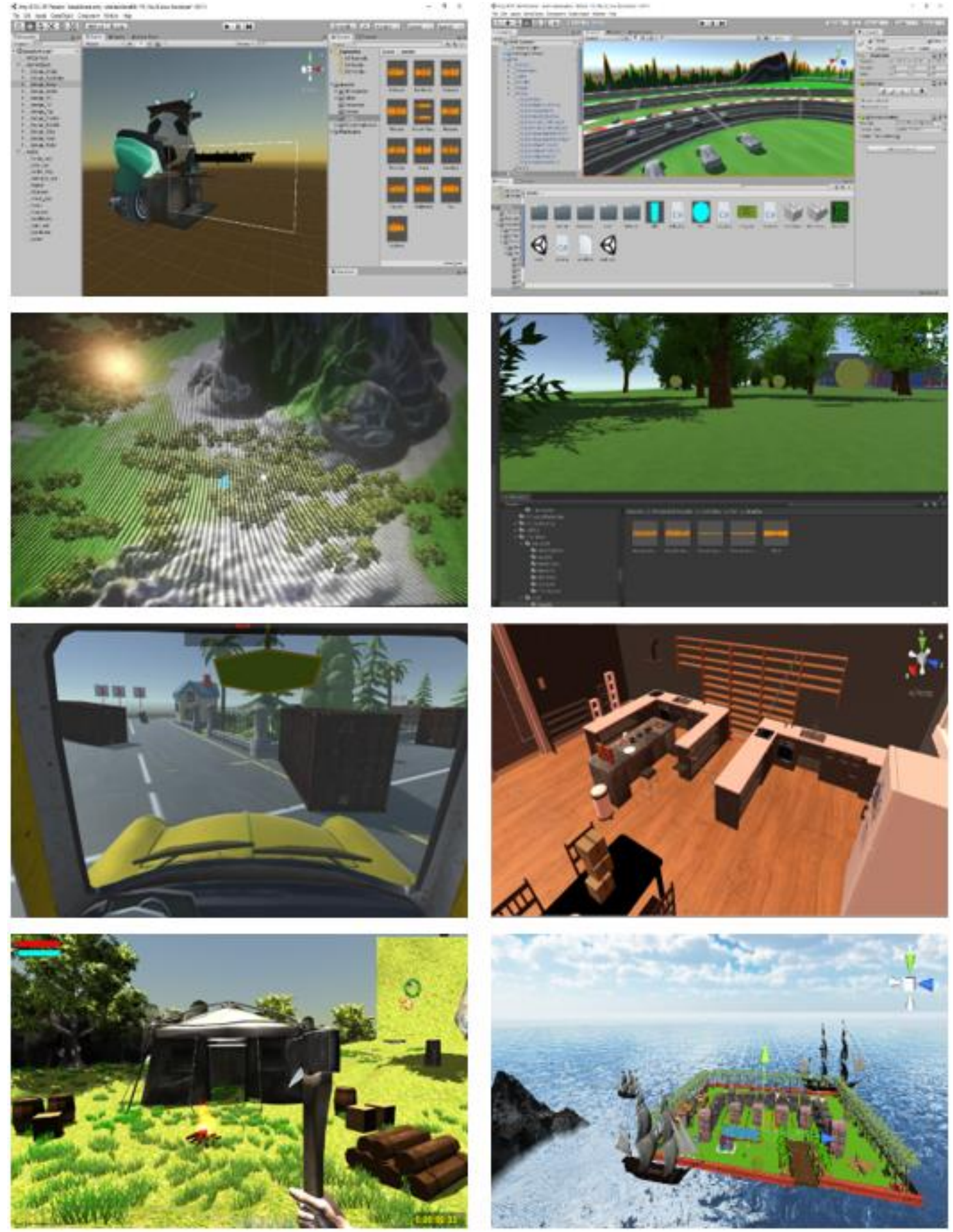

Figure 1. Some design examples of developed products

The processes related to the projects carried out by the groups were evaluated weekly by the researcher and kept as an electronic portfolio (e-portfolio) for assessment and grading. An e-portfolio is considered to be an effective method for students to develop different learning styles, especially in courses based on information technologies (Polat \& Kose, 2013). It is also emphasized that evaluating the content of a project-based course with traditional 
methods will not be an effective method (Frank \& Barzilai, 2004; Gulbahar \& Tinmaz, 2006). For this reason, the e-portfolio assessment method was used to evaluate the achievement levels of the groups. At the end of the PBL, qualitative data were collected from the participants. The data collection process took approximately 50 minutes.

\section{Data Collection Tool}

A structured interview form developed by the researcher was used as a data collection tool in the study. There are open-ended questions in the form. The form is presented in Appendix 1. This form was used to give individuals the opportunity to express their ideas, feelings, and problems on a particular subject in-depth, to reveal differences between individuals in groups more clearly and to obtain in-depth data (Rabiee, 2004; Hannan, 2007). The form was developed in line with the research questions. At the end of the study, participants were asked to answer four questions on the form.

The form was examined by two peers and a field expert and rearranged in line with the feedback received. In addition, for the validity of the form, an interview was conducted with two prospective teachers who were determined randomly among the study groups. During the interview process, the readability of the questions in the form and whether or not appropriate answers were obtained for the research questions were tested.

\section{Data Analysis}

The research data were analyzed by the content analysis method. The main purpose of this method is to reveal the concepts and relationships to explain the data further. In this method, the data are categorized, organized in a logical way, and themes that can explain the data are obtained (Miles \& Huberman, 1994; Yildirim \& Simsek, 2008). The data obtained from the participants were categorized, organized according to the research questions, and presented by visualizing with summary tables. In the process of coding the data, Cohen Kappa's value, which is also regarded as the inter-rater reliability calculation, was used (Cohen, 1968). The necessary assistance was received from a faculty member in the department to calculate the Cohen Kappa value. This value was calculated as 0.82 regarding inter-rater reliability. In this context, it can be said that the coding process is reliable. 


\section{Findings}

\section{Experiences of the Prospective Teachers Regarding the PBL}

According to the results, most of the prospective teachers emphasized that they are satisfied that the training method given with the PBL is practical and that the PBL should be based on in the learning process. In addition, the prospective teachers stated that the PBL gives the opportunity to collaborate, leads them to research, associate their current field knowledge with real-life, improve their skills, and it is a fun method of education. The category, code, and frequency information obtained in line with the experiences of the prospective teachers are presented in Table 3.

Table 3. The prospective teachers' experiences

\begin{tabular}{llll}
\hline & Category & Code & $f$ \\
\hline & Practical & 12 \\
& Opportunity for cooperation & 10 \\
& Referring students to research & 9 \\
& Fun & 9 \\
& Improving learning & 8 \\
Experiences of the prospective & Positive & Providing permanent knowledge & 7 \\
teachers about the lesson & Student-centered & 5 \\
conducted with the PBL & Connected to real life & 4 \\
& & Productive role of students & 4 \\
& Providing self-confidence & 3 \\
& Assigning responsibility & 2 \\
\cline { 2 - 3 } & & Opportunity for a product-oriented evaluation & 2 \\
\hline & Negative & Limited time & 9 \\
& & Difficulty in sharing tasks & 8 \\
\hline
\end{tabular}

Reference was given to the relevant opinion by using the codes "M (Male)" and "F (Female)" instead of the real names of the prospective teachers. For example, "G1_F3" represents the third female prospective teacher in Group 1. The prospective teachers stated that they were mostly pleased with the fact that the course was practice-based and collaborated with other group members. Some prospective teachers reflected their experiences about this situation as follows:

"The project-based learning offers a more permanent learning experience since it is done by applying, seeing, observing, that is, being actively present at all phases of activities..." [G3_F2]. 
"We learned by discovering and researching. That's why our learning was more permanent. We also gained the ability to collaborate and work with the group..."

[G1_F4].

"The course was not boring. The lesson was conducted efficiently by having fun and active participation in the lesson. In addition, our social responsibility awareness has evolved during the project development process..." [G8_M4].

Additionally, some prospective teachers stated negative opinions regarding the PBL. They especially complained about not having enough time in the project development process. In addition, prospective teachers emphasized that group members were not responsible and fair in the process related to their tasks, sometimes there were conflicts among the group members, and this situation negatively affected the project development process. Some prospective teachers expressed their opinions and experiences as follows:

“We couldn't find enough time in the project development process..." [G2_M1].

"It is disadvantageous that the project process is done as a group because every individual may not be able to do their task. This causes the project to fail..."

[G4_M1].

"... They take the easy way out of the course and leave the load on other group members." [G5_F2].

The prospective teachers suggested that the PBL experience improves learning processes, ensures that information is permanent, and gives them a sense of self-confidence and responsibility. They were also pleased to obtain a concrete product at the end of the process.

Difficulties Experienced by the Prospective Teachers in the PBL

The prospective teachers, especially in the PBL, complained about not finding enough resources, not being able to cooperate within the group, and the limited time allocated for the PBL process. They also faced various technical and hardware challenges and stressed that more support should be provided to address these challenges. The category, code, and frequency values of the prospective teachers' difficulties are presented in Table 4. 
Table 4. Difficulties experienced by the prospective teachers

\begin{tabular}{|c|c|c|c|}
\hline & Category & Code & $f$ \\
\hline \multirow{10}{*}{$\begin{array}{l}\text { Difficulties experienced in } \\
\text { the PBL }\end{array}$} & \multirow{10}{*}{$\begin{array}{l}\text { Causes of } \\
\text { difficulties }\end{array}$} & Inability of finding enough resources & 8 \\
\hline & & Failure to cooperate and coordinate in the group & 7 \\
\hline & & Limited time & 6 \\
\hline & & Technical problems (such as coding, design) & 4 \\
\hline & & Experiencing the PBL process for the first time & 3 \\
\hline & & Using unlearned programs for the first time & 3 \\
\hline & & Not getting enough support & 3 \\
\hline & & Inability to generate new ideas & 3 \\
\hline & & Passiveness of the instructor & 2 \\
\hline & & Difficult data collection process & 2 \\
\hline \multirow{10}{*}{$\begin{array}{l}\text { The phases of the PBL in } \\
\text { which the difficulties were } \\
\text { experienced }\end{array}$} & Analysis & Not finding new ideas & 6 \\
\hline & & Lack of information about the PBL & 2 \\
\hline & Design & Failure to cooperate and coordinate in the group & 4 \\
\hline & \multirow{4}{*}{ Development } & Not finding new ideas & 4 \\
\hline & & Failure to cooperate and coordinate in the group & 4 \\
\hline & & Not finding enough resources & 3 \\
\hline & & Lack of technical knowledge & 3 \\
\hline & \multirow[t]{2}{*}{ Implementation } & Not getting official permission for the application & 8 \\
\hline & & Technical problems (such as running the software) & 2 \\
\hline & Evaluation & Limited time & 1 \\
\hline
\end{tabular}

It is significant to note that there are problems related to resources, time, and cooperation among the difficulties experienced by the prospective teachers. Some prospective teachers reflected their experiences on these difficulties as follows:

"While we were researching, we couldn't reach the resources we were looking for..."

[G1_M1].

"Coordination and distribution of tasks among group members was a very troublesome process." [G6_M2].

"Sometimes, there were parts that we could not manage due to lack of time."

[G7_F1].

The difficulties the prospective teachers had during the PBL process were also analyzed according to the phases of the ADDIE model. In this context, it was observed that especially the factors of not being able to generate new ideas and not being able to cooperate among the group members stand out. In addition, it was observed that the candidates were not satisfied with the official procedures they encountered during the implementation of the developed multimedia projects. Some prospective teachers highlighted their experiences regarding these difficulties as follows: 
"I had a hard time in the analysis phase because when creating new applications, new designs, and new ideas, people inevitably have some unexpected difficulties..."

[G7_M2].

"We had difficulties in the development and implementation phases because we could not get permission from the schools to conduct practice..." [G2_F3].

According to the results, it was observed that the prospective teachers are dissatisfied with their first experience of a project making process. In this context, they faced technical problems and complained about not getting enough support. In addition, only one prospective teacher's complaint about the time shortage was noticed during the evaluation phase because it was determined that prospective teachers generally do not encounter difficulties in the evaluation phase.

\section{Discussion and Conclusion}

The aim of this study is to determine the opinions and experiences of the prospective information technologies teachers regarding the PBL. As a result of the research, the vast majority of the participants adopted the PBL. Particularly, the fact that the learning process is practical and consists of group-based activities is seen to have a positive effect on the positive experiences of the participants. The results are similar to the findings of some studies in the literature (Berbegal-Mirabent et al., 2017; Raycheva et al., 2017; Assaf, 2018; Guo et al., 2020). The constructivist approach allows for active learning, and students' participation in research activities according to their learning speed can be a reason for this situation (Chisanu et al., 2012). In addition, given that students generally take courses with theoretical content, it is stated that participation in applied activities is an important variable in students' satisfaction (Chisanu et al., 2012). There are constructivist and cooperative learning activities in the nature of the PBL. In this context, the PBL experiences are considered as an important acquisition for the prospective teachers in the project group to work together on a project or a problem and learn new information together (Whatley, 2012). The fact that the PBL gave the opportunity to these features was thought to be effective in that the participants were satisfied with the practical and group-based activities.

Although the PBL has positive effects, the vast majority of the participants experienced various difficulties. Difficulties such as not finding sufficient resources, not being able to provide cooperation and coordination in the group, complaining about time, 
generating new ideas, and not getting official permission for implementation are the prominent factors. It is argued that these problems play a dominant role in some studies in the literature (Yam \& Rossini, 2010; Dauletova, 2014; Vogler et al., 2018; Raycheva et al., 2017). In this context, it can be argued that these factors arising in the application of the PBL in the process of learning and teaching are among continuous problems. It can be argued that different learning habits caused by the individual characteristics of the participants are effective in experiencing these difficulties. The reason for this is that prospective teachers are not sufficiently coordinated in group activities and that they encounter difficulties in the process of dividing the tasks among group members. In addition, prospective teachers' lack of resources in solving problems may be due to their lack of knowledge, as well as the instructor's lack of feedback and support in the process.

As a result, this study shows that prospective teachers' attitudes towards PBL reflect positively. This method will be effective and useful in the learning process if solutions related to negativities, such as resource, time, and within-group coordination, are resolved during the implementation phase of the PBL. Accordingly, it may be useful to consider the following suggestions:

- The evaluation of the group members can be used as a method to clarify whether the group members participate equally and fairly in the activities to be held during the learning process.

- The fact that the instructors play a more active role in the context of resources and support by examining and following the project process in more depth can make the PBL process more effective.

- The concentration of students in researches to meet their own knowledge gaps in the production of new ideas can help use time effectively in the PBL process.

- In the implementation process, especially public institutions can play a role in the implementation of more flexible and faster formal procedures followed in research in educational activities.

Although the results obtained from this study are adopted as a satisfying, exciting, and continuing teaching approach in the eyes of the students, the study contains some limitations. First of all, the course included in the research is a compulsory one. Secondly, the 
number of students in the study groups is not equal. In addition, the lecturer who taught the course also took part in the research. However, the results of the research are important in terms of presenting findings of the effectiveness and efficiency of the teaching method of the PBL. In this direction, experimental researches based on a different group and course contents to investigate the effectiveness of the PBL can help to obtain more detailed results.

Acknowledgement

The data used in this study was confirmed by the researcher that it belongs to the years before 2020.

Authorship Contribution Statement

Murat ÇOBAN: Conceptualization, providing of software, teaching process, design of the work, literature search, data collection, data analysis, data interpretation, writing - review and editing.

\section{References}

Ahmad, C. N. C., Ching, W. C., Yahaya, A., \& Abdullah, M. F. N. L. (2015). Relationship between constructivist learning environments and educational facility in science classrooms. Procedia-Social and Behavioral Sciences, 191, 1952-1957.

Apaydın, Z., \& Kandemir, M. (2017). The effect of active learning approach jigsaw ii technique on student attitudes relating to science 4th grade science course. Journal of Computer and Education Research, 5(10), 317-334. 10.18009/jcer.336175

Arkun, S. (2007). A study on development process of a multimedia learning environment, according to ADDIE model and students' opinion on the environment (Unpublished master's thesis). Hacettepe University, Ankara.

Assaf, D. (2018). Motivating language learners during times of crisis through project-based learning: Filming activities at the arab international university (AIU). Theory and Practice in Language Studies, 8(12), 1649-1657. https://doi.org/10.17507/tpls.0812.10.

Bell, S. (2010). Project-based learning for the 21st century: Skills for the future. The Clearing House, 83(2), 39-43.

Bender, W. N. (2012). Project-based learning: Differentiating instruction for the 21st century (1st ed.). Thousand Oaks, CA: Corwin.

Berbegal-Mirabent, J., Gil-Doménech, D., \& Alegre, I. (2017). Where to locate? A projectbased learning activity for a graduate-level course on operations management. International Journal of Engineering Education, 33(5), 1586-1597.

Celik, H. C., Ertas, H., \& İlhan, A. (2018). The impact of project-based learning on achievement and student views: The case of AutoCAD programming course. Journal of Education and Learning, 7(6), 67-80. https://doi.org/10.5539/jel.v7n6p67. 
Chen, C. H., \& Yang, Y. C. (2019). Revisiting the effects of project-based learning on students' academic achievement: A meta-analysis investigating moderators. Educational Research Review, 26, 71-81. https://doi.org/10.1016/j.edurev.2018.11.001

Chisanu, J., Sumalee, C., Issara, K., \& Charuni, S. (2012). Design and develop of constructivist learning environment on learning management system. Procedia-Social and Behavioral Sciences, 46, 3426-3430. https://doi.org/10.1016/j.sbspro.2012.06.078

Cohen, J. (1968). Weighted kappa: nominal scale agreement provision for scaled disagreement or partial credit. Psychological Bulletin, 70(4), 213-220.

Danks, S. (2011). The ADDIE model: Designing, evaluating instructional coach effectiveness. ASQ Primary and Secondary Education Brief, 4(5), 1-6.

Dauletova, V. (2014). Expanding omani learners' horizons through project-based learning: A case study. Business and Professional Communication Quarterly, 77(2), 183-203.

Doppelt, Y. (2003). Implementation and assessment of project-based learning in a flexible environment. International journal of Technology and Design Education, 13, 255-272.

Fraenkel, J. R., \& Wallen, N. E. (2000). How to design and evaluate research in education (4th Edt.). London: McGraw Hill.

Frank, M., \& Barzilai, A. (2004). Integrating alternative assessment in a project-based learning course for preservice science and technology teachers. Assessment $\mathcal{E}$ Evaluation in Higher Education, 29(1), 41-61. https://doi.org/10.1080/0260293042000160401

Gulbahar, Y., \& Tinmaz, H. (2006). Implementing project-based learning and e-portfolio assessment in an undergraduate course. Journal of Research on Technology in Education, 38(3), 309-327. https://doi.org/10.1080/15391523.2006.10782462

Guo, P., Saab, N., Post, L. S., \& Admiraal, W. (2020). A review of project-based learning in higher education: Student outcomes and measures. International Journal of Educational Research, 102, 101586. https://doi.org/10.1016/j.ijer.2020.101586

Hannan, A. (2007). Interviews in education research. Retrieved June 18, 2020, from https://eclass.aspete.gr/modules/document/file.php/EPPAIK269/UsingInterviewsinEd ucationResearch.pdf.

Holm, M. (2011). Project-based instruction: A review of the literature on effectiveness in prekindergarten through 12th grade classrooms. Insight: Rivier Academic Journal, 7(2), 1-13.

Holmes, L. M. (2012). The effects of project based learning on 21st century skills and no child left behind accountability standards (Doctoral dissertation). Retrieved from ProQuest Dissertations and Theses database. (3569441).

Krajcik, J. S., \& Czerniak, C. M. (2014). Teaching science in elementary and middle school: A project-based approach (4th ed.). New York, NY: Routledge.

Krajcik, J. S., \& Shin, N. (2014). Project-based learning. In R. K. Sawyer (Ed.). The Cambridge handbook of the learning sciences (pp. 275-297). (2nd ed.).

Lenz, B., Wells, J., \& Kingston, S. (2015). Transforming schools using project-based learning, performance assessment, and common core standards (1st ed.). San Francisco, CA: Jossey-Bass. 
Markham, T., Larmer, J., \& Ravitz, J. (2003). Project based learning handbook: A guide to standards-focused project based learning for middle and high school teachers (2nd ed.). Novato, CA: Buck Institute for Education.

Miles, M, B., \& Huberman, A. M. (1994). Qualitative data analysis: An expanded Sourcebook. (2nd ed). Thousand Oaks, CA: Sage.

Polat, M., \& Kose, Y. (2013). Perceptions of primary education teachers towards the use of eportfolio as a tool of performance evaluation in schools. Journal of Computer and Education Research, 1(1), 57-82.

Rabiee, F. (2004). Focus-group interview and data analysis. Proceedings of the Nutrition Society, 63(4), 655-660. https://doi.org/10.1079/PNS2004399

Raycheva, R. P., Angelova, D. I., \& Vodenova, P. M. (2017). Project-based learning in engineering design in bulgaria: expectations, experiments and results. European Journal of Engineering Education, 42(6), 944-961.

Sadeghi, H., Biniaz, M., \& Soleimani, H. (2016). The impact of project-based language learning on Iranian EFL learners comparison/contrast paragraph writing skills. International Journal of Asian Social Science, 6(9), 510-524.

Saraçoglu, M., \& Kahyaoğlu, M. (2018). Examination of secondary school students' scientific inquiry skills perceptions in term of curiosity, motivation and attitude. Journal of Computer and Education Research, 6(12), 358-376. 10.18009/jcer.472673

Tierney, G., Goodell, A., Nolen, S. B., Lee, N., Whitfield, L., \& Abbott, R. D. (2020). (Re) Designing for engagement in a project-based AP environmental science course. The Journal of Experimental Education, 88(1), 72-102.

Tseng, K.-H., Chang, C.-C., Lou, S.-J., \& Chen, W.-P. (2013). Attitudes towards science, technology, engineering and mathematics (STEM) in a project-based learning (PjBL) environment. International Journal of Technology and Design Education, 23(1), 87-102.

Vogler, J. S., Thompson, P., Davis, D. W., Mayfield, B. E., Finley, P. M., \& Yasseri, D. (2018). The hard work of soft skills: Augmenting the project-based learning experience with interdisciplinary teamwork. Instructional Science, 46(3), 457-488.

Whatley, J. (2012). Evaluation of a team project based learning module for developing employability skills. Issues in Informing Science and Information Technology, 9, 75-92.

Wu, T. T., Huang, Y.M., Su, C. Y., Chang, L., \& Lu, Y. C. (2018). Application and analysis of a mobile e-book system based on project-based learning in community health nursing practice courses. Journal of Educational Technology \& Society, 21(4), 143-156. Retrieved September 22, 2020 from https://www.learntechlib.org/p/190831/

Yam, L. H. S., \& Rossini, P. (2010). Effectiveness of project-based learning as a strategy for property education. Pacific Rim Property Research Journal, 16(3), 291-313.

Yildirim, A., \& Simsek, H. (2008). Qualitative research methods in social sciences. Ankara Seckin Publications. 


\section{Appendix 1:}

\section{Students' Opinions on the Project-Based Learning}

Dear students;

You have taken the Multimedia Design and Production course this semester with a project-based learning method. Your answers to this form are important for you to have a better education. The information you provide will not be shared with third parties and will only be used in the context of academic study. Thank you for your responses.

\begin{tabular}{|l|}
\hline Important points you want to share: \\
\hline Are you satisfied with the conduct of the lesson within the scope of Project Based Learning (PBL)? \\
No (Why?): \\
\hline What do you think are the advantages and disadvantages of learning with the PBL? \\
Advantages: \\
Disadvantages: \\
\hline What difficulties did you encounter during your teaching process with the PBL? \\
\hline \\
\hline In which phase of the teaching process with the PBL (Analysis, Design, Development, \\
\hline Implementation, Evaluation) did you have more difficulty? Why? \\
\hline
\end{tabular}

\section{Copyright $\odot$ JCER}

JCER's Publication Ethics and Publication Malpractice Statement are based, in large part, on the guidelines and standards developed by the Committee on Publication Ethics (COPE). This article is available under Creative Commons CC-BY 4.0 license (https://creativecommons.org/licenses/by/4.0/) 